DOI: 10.20472/IAC.2017.029.019

\title{
BRUNELA KULLOLLI
}

“Aleksander Moisiu" University of Durres, Albania

\section{LAW AND SOCIETY THE APPLICABILITY OF THE CONVENTION EUROPEAN COMMISSION ON HUMAN RIGHTS CONTRACTUAL RELATIONS}

\begin{abstract}
:
This article analysis the idea that contractual freedom may be limited by the European Convention on Human Rights is not such an easy to admit. Indeed, it is a matter of imposing on private persons the respect, which they have not concluded, by hypothesis an international treaty,.Obviously, only contracting states are obliged to respect the European Convention on Human Rights, and this evidence can be justified by an immemorial tradition: "public liberties have been affirmed by their opposability to the State, and more generally, to the public power.Human rights are then analyzed in a vertical relationship with the State ".

The first part gives, of the restriction and application field to the European Convention on Human Rights. The theory of the horizontal effect constitutes a pass everywhere allowing the judge to open all locks to contractual obligations. In summary, although all contracts are theoretically subject to the Convention European Commission on Human Rights, in reality, only certain types of Contracts, presenting a particular 'profile', are actually the subject of a Control of conventionality.

The second part is concentrated, the modulation sanctions to the clauses offensive of Human Rights. The protection of fundamental rights is only effective if the harm inflicted on them results in the imposition of a genuine sanction. .Indeed "it is already a long time that the specialists of the public freedoms and human rights highlighted.

The conclusion is, therefore, simple: since the internal court is faced with a clause infringing a right enshrined in the European Convention on Human Rights, it must sanction that infringement and must sanction it by the nullity of the clause. The penalty for infringement of a fundamental right is therefore not systematically the nullity of the contested clause; It may also consist of a "reconfiguration" of the effects of this clauses.

High Court refuses any "additive effect" to the European Convention Human rights, which cannot, therefore, be regarded as a source of complementary obligations. Some see in this judgment the affirmation of a principle of "contractual secularism"; We see above all further proof of caution which guides the judge in his application of the European Convention on rights to contractual relations.
\end{abstract}

\section{Keywords:}

contract law ,internal law ,contractual relation, internal court, clauses, European Convention Human rights

JEL Classification: K33 